undergraduates and postgraduate students, nearly double that of nine years ago, Mr. Crosland said that "most of the credit for this quite remarkable achievement lies with the universities themselves". But the government was well aware of the high priority necessary for higher education and research and had backed this decision with increasing financial support. Mr. Crosland rejected the notion that the universities have been meanly treated by successive governments. Within the past five years the University Grants Committee has increased university expenditure from $£ 80$ million a year, about eight per cent of all educational spending, to $£ 207$ million, or $12 \frac{1}{2}$ per cent. In spite of the great expansion of students, the ratio of students to staff had remained constant at about sevenand-a-half. At the same time, resources devoted to university building over the last ten years had increased tenfold. In response to the Flowers Report, the Government had also allocated about $£ 20$ million to universities over the next six years for new computers and related costs. "This is a very substantial additional expenditure which perhaps has been too little noticed in the universities," Mr. Crosland added.

Both undergraduate and graduate studies are far ahead of the Robbins Report projections. The undergraduate enrolment for 1966-67 should be 189,000, or 2,000 more than originally estimated, while nearly a quarter of last year's graduates-13,500 - stayed on for postgraduate work, thus more than doubling the estimated growth rate. This development, said Mr. Crosland, "has resulted from the cumulative decisions of all the universities in the country, and only incidentally from national policy in matters such as postgraduate awards." He concluded that the Government's role is to keep national issues in the forefront of academic discussion, and to create a climate of opinion in which close involvement with the social and economic needs of the nation is a respectable aspiration for a university.

\section{Uranium in Europe}

THe Euratom organization persists in taking what the stock exchanges would call a bullish view of the uranium market. In 1963, when uranium was something of a drug on the market and when the British Government was having to explain to the Canadians why the United Kingdom Atomic Energy Authority wished to stretch out jts contracts to buy uranium from Canadian mines, Euratom published a report which drew attention to the likelihood of scarcity (EUR 414c-The Problem of Uranium Resources and the Long-Term Supply Position). Briefly, the estimates compiled in 1963 suggested that Europe as a whole would need something like 100,000 metric tons of uranium metal in the decade $1970-80$, and that only some 15,000 tons of this would be supplied from within Europe at a reasonably competitive price of around $\$ 8$ for a pound of $\mathrm{U}_{3} \mathrm{O}_{8}$. One immediate result, within the six countries of Euratom, was to stimulate uranium prospecting in Europe. Some of the results of this work are now described in the document Les Ressources en Uranium dans la Communauté Européenne published at Brussels.

The most remarkable change in the past three years has been a cheerful upward revision of the estimates of the potential uranium resources of Europe. It is true that the Benelux countries (Belgium, Luxembourg and the Netherlands) are written off as contribu- tors, but it appears that France, West Germany and Italy are better off than has hitherto been thought. More detailed examination of uranium ore deposits known for some years has led to increases of estimates of their potential. Hunting for new kinds of uranium deposits has also turned out to be successful. The result is that the Working Party responsible for the survey considers that the proved reserves of uranium ore, known to be equivalent to 31,000 tonnes in 1964 , could be increased by up to 40,000 tonnes by means of a sufficiently energetic programme of exploration. Some of this addition to present reserves would come from the discovery of new deposits, and some from the extension of deposits at present being worked. France is thought to contain half the uranium as yet undiscovered, while Italy and West Germany share the rest. The Working Party has a number of suggestions to make about the future exploration for uranium in Europe, not the least constructive of which is the suggestion that there should be better liaison between the geologists. But, for all its optimism about the future of uranium supplies, there remains an unhappy discordance between potential supply and likely demand. Even if prospecting turns out to be as successful "as it seems reasonable to hope, the reserves will, however, remain insufficient for the needs of the community as a whole in the decades ahead ..."

\section{Drilling Deep}

IT should soon be known whether the National Science Foundation will have to buy its way out of the contracts signed for the equipment needed for drilling the Mohole, or whether the project will be allowed to $\operatorname{limp}$ along on a somewhat straitened budget. Earlier this year the appropriate committee of the United States House of Representatives declined to vote money for next year's operations, and thus put in jeopardy the construction of the Mohole drilling barge, estimated to cost $\$ 27$ millions and due to start experimental drilling in the Pacific during 1967. Now it is up to the Independent Offices Appropriations Subcommittee of the United States Senate to decide whether there shall be some loosening of the public pursestrings. At this stage it is unlikely that the sponsors of the project will get the whole of the $\$ 127$ millions now thought necessary to complete the Mohole, though it would be entirely sensible if the Senate decided to complete the barge on which work has begun, and to provide funds for a modest programme of experimental drilling in 1967 and 1968. After all, nobody questions the value of deep boreholes, but merely the wisdom and feasibility of going in one leap to the Mohorovicic discontinuity on a fixed budget, even if that budget is eight times the cost originally estimated.

Some of the artlessness of the Mohole project can be found in the record of the symposium on Drilling for Scientific Purposes held in Ottawa last year under the auspices of the International Upper Mantle Committee (Queen's Printer, Ottawa, 75 cents). At the symposium Professor H. H. Hess of Princeton described a meeting in Washington in March, 1957, at which eight people were gathered "to analyse projects submitted from earth scientists of the country. We had something like sixty projects to review in two days ... we were rather tired, and Walter Munk mentioned that none of these proposals was really fundamental to an under- 